\title{
ANALISIS PERBANDINGAN FRAUD PENTAGON DENGAN BENEISH RATIO DALAM PENDETEKSIAN FRAUDULENT FINANCIAL REPORTING DENGAN OPINI AUDIT SEBAGAI VARIABEL MODERATING
}

\author{
ARIS SANULIKA, WAHYU NURUL HIDAYATI* \\ Universitas Pamulang, Tangeran Selatan, Indonesia \\ *Email:dosen01236@unpam.ac.id
}

\begin{abstract}
Fraudulent Financial Reporting is a deliberate attempt by a company to deceive and mislead users of financial statements, especially investors and creditors, by presenting and manipulating the material value of financial statements. This study aims to determine how the auditor's opinion can moderate the comparative analysis of the pentagon fraud with the beneish ratio in the detection of Fraudulent Financial Reporting. The type of data used in this study is comparative quantitative data. The data source in this study is secondary data. The population in this study are banking companies listed on the IDX. With a sample of 16 publicly traded companies engaged in financial and banking institutions and were listed on the Indonesia Stock Exchange in 2014-2017. The results of this study indicate that of 64 samples there were $12.5 \%$ which indicated that the financial statements had been manipulated. Auditor opinions can increase the influence of Financial Stability, external auditor quality, change in auditor, change of directors, days sales in receivables index, sales gross margin index, Asset Quality Index, growth index, depreciation index, sales, and general administration expenses index, leverage index, total accrual to Fraudulent Financial Reporting. Beneish Ratio affects Fraudulent Financial Reporting while Fraud Pentagon does not affect Fraudulent Financial Reporting
\end{abstract}

\section{Keywords: Fraudulent Financial Reporting; Opini, Beneish Ratio; Fraud Pentagon}

\section{PENDAHULUAN}

Fraudulent Financial Reporting merupakan suatu usaha yang dilakukan dengan sengaja oleh perusahaan untuk mengecoh dan menyesatkan para pengguna laporan keuangan, terutama investor dan kreditur, dengan menyajikan dan merekayasa nilai material dari laporan keuangan (Sihombing dan Rahardjo, 2014). Sektor lembaga keuangan dan perbankan merupakan sektor paling banyak 
Jurnal Ilmiah Akuntansi Universitas Pamulang - Vol. 9, No. 1, Januari 2021 - Sanulika \& Hidayati

mengalami kasus fraud dibandingkan dengan sektor lain, menurut survey yang dilakukan Association of Certified Fraud Examiner ACFE tahun 2014.

Fenomena kasus kecurangan atas laporan keuangan pernah dilakukan oleh PT Sunprima Nusantara Pembiayaan (SNP Finance) perusahaan pembiayaan yang berada di bawah naungan Columbia Group yang di dalam laporan keuangan terlihat dalam kondisi yang baik-baik saja. Bahkan perusahan pembiayaan tersebut mendapat rating id A atau stabil dari Pefindo atas rating utang perseroan pada Maret 2018. Akan tetapi hal tersebut berbanding terbalik pada 9 Mei 2018 karena salah satu kupon Medium Term Notes (MTN) yang diterbitkan SNP mengalami gagal bayar. Diduga laporan keuangan yang disampaikan SNP Finance dimanipulasi, oleh karena itu otoritas jasa keuangan membekukan kegiatan usaha SNP.

Fraud dapat dinilai dan ditimbang dari berbagai segi perspektif salah satunya dengan menggunakan pengujian teori fraud pentagon yang dikemukakan oleh Crowe (2011) yang terdiri dari lima elemen indikator di dalamnya yaitu: Pressure, Opportunity, Rationalization, Capability, dan Arrogance. Selain menggunakan pentagonal fraud, Fraudulent Financial Reporting juga dapat dideteksi dengan Beneish ratio.

\section{LANDASAN TEORI}

\section{Agency Theory (Teori Keagenan)}

Teori keagenan dijelaskan dengan hubungan antara pihak pemegang saham sebagai prisipal dan management sebagai agen. Hubungan ini ada atas kerja sama dari prinsipal yang mempercayakan agen yaitu pihak agen untuk mengelola modal prinsipal, dan pihak prisipal mendelegasikan wewenang pada agennya untuk membuat keputusan.

Prinsipal mengaharapkan laba tinggi atas investasi yang dikeluarkan untuk perusahaan, sedangkan agen mempunyai kepentingan tersendiri yaitu untuk mendapatkan gaji atau imbal hasil atas kinerjanya. Hal ini menunjukan adanya benturan kepentingan antara prinsipal dan agen yaitu pemilik modal dan para pengelola modal atau manajemen perusahaan. Adanya benturan kepentingan antar agen dan prinsipal ini sering disebut pula dengan conflict of interest.

\section{Fraud Pentagon Theory}

Salah satu teori dasar yang digunakan untuk menjelaskan fraud adalah fraud triangle. Teori ini ditemukan oleh Donald R. Cressey pada tahun 1953. Setelah teori fraud yang dikemukakan oleh D.R. Cressey, ternyata terjadi perluasan yang dipicu oleh keadaan atau kondisi saat ini yaitu teori fraud pentagon yang dikenalkan oleh Crowe Howarth pada Tahun 2011. fraud Pentagon terdiri atas pressure, opportunity, rationalization, competence dan arrogance.

\section{Beneish Teori}

Manipulasi atau fraud dalam perusahaan dapat diindikasi dengan model perhitungan yang akan membantu untuk mendeteksi pergerakan yang tidak wajar

* Corresponding author's e-mail: dosen01236@unpam.ac.id

http://openjournal.unpam.ac.id/index.php/JIA 
Jurnal Ilmiah Akuntansi Universitas Pamulang - Vol. 9, No. 1, Januari 2021 - Sanulika \& Hidayati

dalam laporan keuangan. Salah satu model perhitungan yang dpat digunakan yakni Beneish M-Score Model (Beneish, 2012). Delapan variable rasio perhitungan yang digunakan dalam model ini untuk mengindikasi apakah perusahaan mempunyai indikasi untuk melakukan manipulasi atas laporan keuangan. Delapan variabel yang digunakan dalam Beneish M-Score Model yaitu : Days Sales in Receivable Index (DSRI)Gross Margin Index (GMI) Asset Quality Index (AQI) Sales growth index (SGI) Depreciation Index (DEPI) Sales and General Administration Expenses Index (SGAI) Leverage Index (LVGI) Total Accrual (TATA)

\section{Opini Audit}

Opini yang terdapat dalam laporan audit sangat penting sekali dalam proses audit atapun proses atestasi lainnya karena opini tersebut merupakan informasi utama yang dapat diinformasikan kepada pemakai informasi tentang apa yang dilakukan auditor dan kesimpulan yang diperolehnya. Pemberian opini audit dilakukan oleh auditor melalui beberapa tahap proses audit sehingga auditor dapat memberikan kesimpulan atas opini yang harus diberikan terhadap laporankuangan klien yang telah diaudit. Berdasarkan standar profesional akuntan publik seksi 508, pendapat auditor dikelompokkan ke dalam lima tipe, yaitu:

a. Pendapat Wajar Tanpa Pengecualian (Unqualified)

b. Pendapat Wajar Tanpa Pengecualian dengan Paragraf Penjelas (Unqualified Opinion with Explanatory Paragraph)

c. Pendapat Wajar dengan Pengecualian (Qualified)

d. Pendapat tidak Wajar (Adverse)

e. Pernyataan tidak Memberikan Pendapat (Disclaimer)

\section{Fraudulent Financial Reporting}

Association of Certified Fraud Examiners (2000) menjelaskan Fraudulent Financial Reporting atau kecurangan pelaporan keuangan, sebagai berikut:

"The deliberate misrepresentation of the financial condition of an enterprise accomplished through the intentional misstatement or omission of amounts or disclosures in the financial statements in order to deceive financial statement users."

Yang dimaksudkan ialah penyampaian yang salah tentang kondisi keuangan perusahaan yang disengaja melalui pernyataan yang salah karena disengaja atau kelalaian perhitungan jumlah atau kelalaian dalam pengungkapan laporan keuangan untuk memperdaya pengguna laporan. Fraud merupakan suatu kondisi yang mungkin akan ditemukan oleh auditor dalam suatu audit. Auditor mungkin akan menemui berbagai temuan dan bentuk yang terjadi di lapangan. Bukan hanya itu mungkin auditor juga akan melihat berbagai cara yang dilakukan oleh pelaku dalam melakukan fraud serta siapa saja pelaku yang memungkinkan untuk melakukan fraud. 
Jurnal Ilmiah Akuntansi Universitas Pamulang - Vol. 9, No. 1, Januari 2021 - Sanulika \& Hidayati

\section{Model Penelitian}

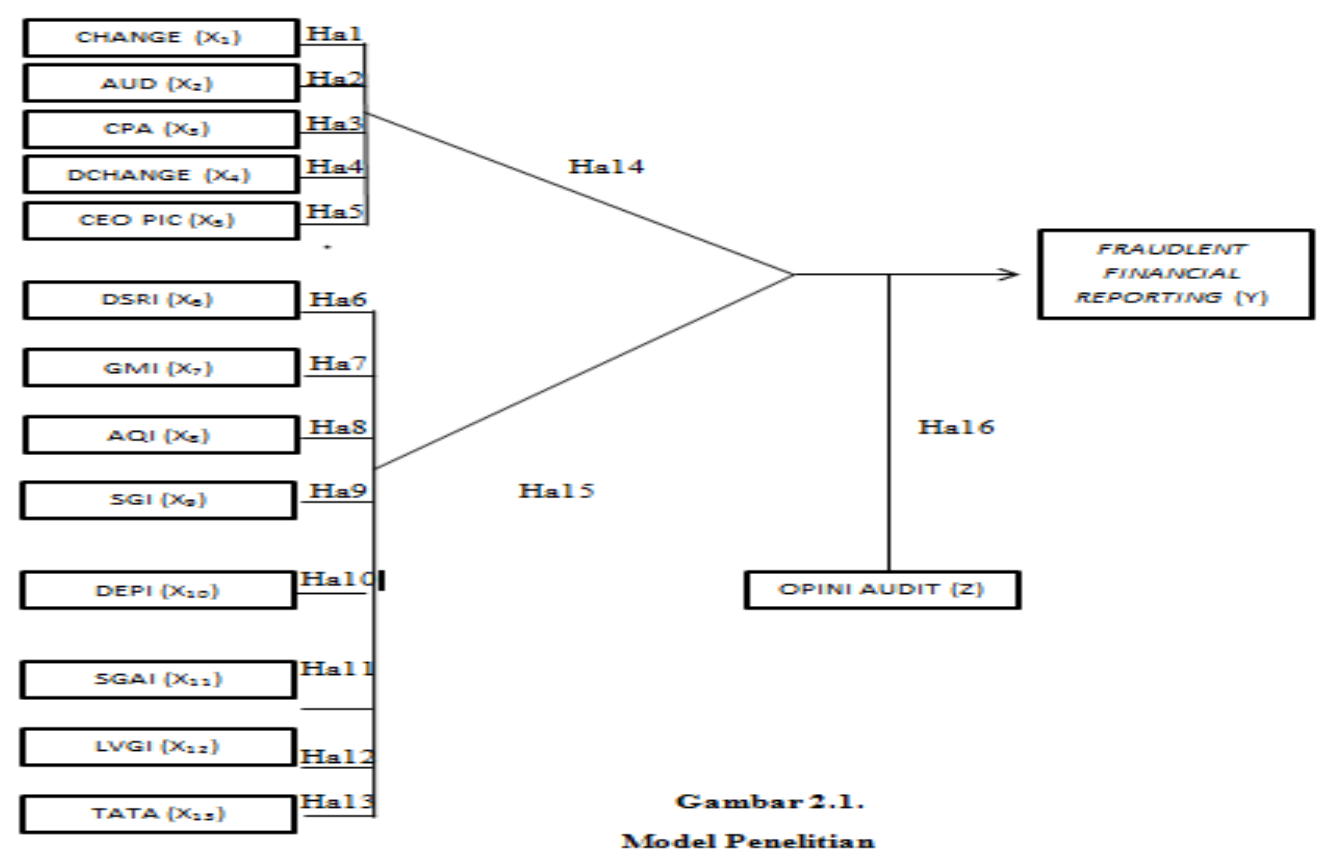

Ha1. Terdapat pengaruh Financial Stability terhadap Fraudulent Financial Reporting secara parsial.

Ha2. Terdapat pengaruh Kualitas Auditor Eksternal terhadap Fraudulent Financial Reporting secara parsial.

Ha3. Terdapat pengaruh change in auditor terhadap Fraudulent Financial Reporting secara parsial.

Ha4. Terdapat pengaruh pergantian direksi perusahaan terhadap Fraudulent Financial Reporting reporting secara parsial.

Ha5. Terdapat pengaruh Frequent Number of CEO's Picture terhadap Fraudulent Financial Reporting secara parsial.

Ha6. Terdapat pengaruh days sales in receivable index terhadap Fraudulent Financial Reporting secara parsial.

Ha7. Terdapat pengaruh gross margin index terhadap Fraudulent Financial Reporting secara parsial.

Ha8. Terdapat pengaruh Asset Quality Index terhadap Fraudulent Financial Reporting secara parsial.

Ha9. Terdapat pengaruh sales growth index terhadap Fraudulent Financial Reporting secara parsial.

Ha10. Terdapat pengaruh depreciation index terhadap Fraudulent Financial Reporting secara parsial.

Ha11. Terdapat pengaruh sales and general administration expenses index terhadap Fraudulent Financial Reporting secara parsial.

Ha12. Terdapat pengaruh leverage index terhadap Fraudulent Financial Reporting secara parsial. 
Jurnal Ilmiah Akuntansi Universitas Pamulang - Vol. 9, No. 1, Januari 2021 - Sanulika \& Hidayati

Ha13. Terdapat pengaruh total accrual terhadap Fraudulent Financial Reporting secara parsial

Ha14. Terdapat pengaruh Financial Stability, kualitas auditor eksternal, kualitas auditor eksternal, change in auditor, change of drectors terhadap Fraudulent Financial Reporting secara simultan.

Ha15. Terdapat pengaruh days sales in receivable index, sales gross margin index, Asset Quality Index, growth index, depreciation index, sales and general administration expenses index, leverage index, total accrual terhadap Fraudulent Financial Reporting secara simultan.

Ha16. Opini audit mampu memoderasi Financial Stability, kualitas auditor eksternal, change in auditor, change of drectors, days sales in receivable index, sales gross margin index, Asset Quality Index, growth index, depreciation index, sales and general administration expenses index, leverage index, total accrual terhadap Fraudulent Financial Reporting

\section{METODE PENELITIAN}

Penelitian ini menggunakan metode penelitian komparatif yang mengambil sampel perusahaan perbankan yang terdaftar di BEI periode 2014-2017.

Pressure yang dikategorikan pada Financial Stability $\left(\mathrm{X}_{1}\right)$

Financial Stability merupakan keadaan yang menggambarkan kondisi keuangan perusahaan dalam kondisi stabil. Penilaian mengenai kestabilan kondisi keuangan perusahaan dapat dilihat dari bagaimana keadaan asetnya.

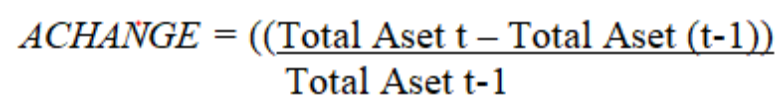

Opportunity yang dikategorikan pada Quality Of External Audits(AUD) ( $\left.\mathrm{X}_{2}\right)$ Kualitas audit eksternal (AUD) diukur dengan menggunakan variabel dummy yaitu jika perusahaan diaudit menggunakan jasa audit "KAP BIG 4" diberi kode 1 (satu) dan perusahaan yang diaudit tidak menggunakan jasa audit "KAP BIG 4" diberi kode 0 (nol).

\section{Rationalization yang dikategorikan dalam Change Auditor (CPA) (X3)}

Penelitian ini memproksikan rationalization dengan pergantian kantor akuntan publik ( $\triangle \mathrm{CPA})$ yang diukur dengan variabel dummy di mana apabila terdapat perubahan Kantor Akuntan Publik selama periode 2014- 2017 maka diberi kode1, sebaliknya apabila tidak terdapat perubahan kantor akuntan publik selama periode 2014-2017 maka diberi kode 0 .

\section{Competence yang dikategorikan dalam Change of Directors (DCHANGE) $\left(\mathbf{X}_{4}\right)$}

Untuk mengetahui adanya kemampuan individu ketika menghadapi kesempatan untuk melakukan fraud maka variabel perubahan direksi (DCHANGE) diukur dengan menggunakan variabel dummy yang dapat dikategorikan menjadi 2(dua)

* Corresponding author's e-mail: dosen01236@unpam.ac.id

http://openjournal.unpam.ac.id/index.php/JIA 
Jurnal Ilmiah Akuntansi Universitas Pamulang - Vol. 9, No. 1, Januari 2021 - Sanulika \& Hidayati

kategori yaitu jika terjadi perubahan direksi perusahaan maka diberi kode 1 (satu) dan apabilatidak terjadi perubahan direksi perusahaan maka diberi kode 0 (nol).

Arrogance yang dikategorikan dalam Frequent Number of CEO's Picture $\left(\mathrm{X}_{5}\right)$ Banyaknya foto CEO yang terpampang dalam laporan keuangan dapat mempresentasikan tingkat arogansi yang dimiliki oleh CEO tersebut. Variabel ini dapat diukur dengan menghitung total foto CEO yang terpampang dalam sebuah laporan tahunan perusahaan periode 2014-2017.

Days Sales in Receivable Index (DSRI) $\left(\mathrm{X}_{6}\right)$

Rasio ini membandingkan piutang usaha terhadap penjualan yang dihasilkan perusahaan pada suatu tahun $(\mathrm{t})$ dan tahun sebelumnya $(\mathrm{t}-1)$.

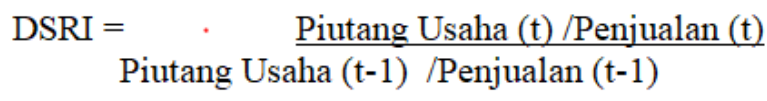

Beneish (1999) menyatakan bahwa jika DSRI >1, maka hal ini menunjukkan adanya peningkatan atas jumlah piutang usaha yang dimiliki. Kondisi tersebut mengindikasikan terjadinya earning overstatement.

Gross Margin Index (GMI) ( $\left.\mathrm{X}_{7}\right)$

Rasio ini membandingkan perubahan laba kotor yang dihasilkan perusahaan pada suatu tahun $(\mathrm{t})$ dan tahun sebelumnya $(\mathrm{t}-1)$.

\section{GMI $=\cdot \underline{\text { Laba Kotor }(\mathrm{t}-1) / \text { Penjualan (t-1) }}$ Laba Kotor (t) /Penjualan (t)}

Beneish (1999) menyatakan bahwa jika GMI >1, maka hal ini menunjukkan terjadinya penurunan atas laba kotor perusahaan yang merepresentasikan prospek perusahaan yang mengalami penurunan. Kondisi ini mengindikasikan terjadinya earning overstatement.

\section{Asset Quaity Index (AQI) (X8)}

Rasio ini membandingkan aktiva tidak lancar yang dimiliki oleh perusahaan selain aktiva tetap dengan total aktiva perusahaan pada suatu tahun (t) dan tahun sebelumnya $(\mathrm{t}-1)$.

$$
\mathrm{AQI}=\frac{1-\operatorname{AktivaLancar}(\mathrm{t})+\operatorname{AktivaTetap}(\mathrm{t}): \operatorname{TotalAktiva}(\mathrm{t})}{1-\operatorname{AktivaLancar}(\mathrm{t}-1)+\operatorname{AktivaTetap}(\mathrm{t}-1): \operatorname{TotalAktiva}(\mathrm{t}-1)}
$$

Beneish (1999) menyatakan bahwa jika AQI >1, maka hal ini menunjukkan terjadinya penurunan atas kualitas aktiva. Dengan demikian terjadi peningkatan atas jumlah aktiva tidak lancar yang dapat memberikan manfaat di masa depan dan peningkatan jumlah beban yang ditangguhkan. Beneish (1999) menyatakan bahwa kondisi ini mengindikasikan terjadinya earning overstatement. 
Jurnal Ilmiah Akuntansi Universitas Pamulang - Vol. 9, No. 1, Januari 2021 - Sanulika \& Hidayati

Sales Growth Index (SGI) (X9)

Rasio ini membandingkan penjualan pada suatu tahun ( $\mathrm{t}$ ) dan tahun sebelumnya $(\mathrm{t}-1)$.

$\mathrm{SGI}=\underline{\text { Penjualan }(\mathrm{t})}$

Penjualan $(\mathrm{t}-1)$

Jika SGI >1, maka hal ini menunjukkan terjadinya peningkatan atas penjualan, sedangkan penurunan atas rasio ini menunjukkan adanya penurunan atas penjualan. Oleh karena itu, Beneish (1999) menyatakan bahwa jika SGI >1, maka hal ini mengindikasikan terjadinya earning over statement.

\section{Depreciation Index (DEPI) (X10)}

Rasio ini membandingkan beban depresiasi terhadap aktiva tetap sebelum depresiasi pada suatu tahun $(\mathrm{t})$ dan tahun sebelumnya $(\mathrm{t}-1)$.

\section{DEPI $=\quad$ Depresiasi(t-1) $/$ Depresiasi $(\mathrm{t}-1)+$ AktivaTetap $(\mathrm{t}-1)$ Depresiasi(t) / Depresiasi (t) + AktivaTetap(t)}

Jika DEPI >1, maka hal ini menunjukkan terjadinya penurunan atas depresiasi aktiva tetap sedangkan penurunan atas rasio ini menunjukkan adanya peningkatan atas tingkat depresiasi aktiva tetap. Oleh karena itu, Beneish (1999) menyatakan bahwa jika DEPI $>1$, maka hal ini mengindikasikan terjadinya earning overstatemen.

\section{Sales And General Administration Expenses Index (SGAI) (X11)}

Rasio ini membandingkan beban penjualan, umum, dan administrasi terhadap penjualan pada suatu tahun $(\mathrm{t})$ dan tahun sebelumnya $(\mathrm{t}-1)$.

$$
\mathrm{SGAI}=\frac{\operatorname{SGAI}(\mathrm{t}) / \text { Penjualan }(\mathrm{t})}{\mathrm{SGAI}(\mathrm{t}-1) / \text { Penjualan }(\mathrm{t}-1)}
$$

Jika SGAI <1, maka hal ini menunjukkan terjadinya penurunan atas beban operasional perusahaan atau terjadi kenaikan atas penjualan. Beneish (1999) menyatakan bahwa jika SGAI <1, maka hal ini mengindikasikan terjadinya earning overstatement.

\section{Leverage Index (LVGI) (X2)}

Rasio ini membandingkan jumlah hutang terhadap total aktiva pada suatu tahun (t) dan tahun sebelumnya ( $\mathrm{t}-1)$.

\section{LVGI $=\quad$ Total Kewajiban $(\mathrm{t}) /$ Total Aktiva $(\mathrm{t})$ \\ Total Kewajiban (t-1) / Total Aktiva (t-1)}


Jurnal Ilmiah Akuntansi Universitas Pamulang - Vol. 9, No. 1, Januari 2021 - Sanulika \& Hidayati

Beneish (1999) menyatakan bahwa jika LVGI >1, maka hal ini mengindikasikan kondisi perusahaan yang potensial atas terjadinya earning overstatement untuk memenuhi kewajibannya.

\section{Total Accrual (TATA) (X3)}

\section{$\operatorname{TATA}=\underline{\text { Laba Usaha }(\mathrm{t}) \text { - Arus Kas dari Aktivitas Operasi ( } \mathrm{t})}$ \\ Total Aktiva (t)}

Total akrual yang tinggi menunjukkan tingginya jumlah laba akrual yang dimiliki oleh perusahaan. Hal ini menunjukkan bahwa jumlah kas atas laba yang dihasilkan ialah rendah. Beneish (1999) menyatakan bahwa nilai TATA yang tinggi (positif) mengindikasikan kondisi perusahaan yangpotensial atas terjadinya earning overstatement melalui peningkatan atas transaksi akrual dalam pengakuan pendapatan.

\section{Opini Audit (Z)}

Variabel opini audit menggunakan variabel dummy. Jika perusahaan klien menerima opini selain wajar tanpa pengecualian (unqualified) pada periode tahun lalu maka diberikan nilai 1. Sedangkan jika perusahaan klien menerima opini wajar tanpa pengecualian (unqualified) pada periode tahun lalu maka diberikan nilai 0 (Damayanti dan Sudarma,2008).

\section{Fraudulent Financial Reporting (Y)}

Untuk menentukan apakah perusahaan terindikasi melakukan manipulasi (fraud) atau tidak, peneliti menggunakan model perhitungan Beneish M-Score. Jika Benesih M-Score lebih besar dari-2.22 mengindikasikan bahwa laporan keuangan telah dimanipulasi dan jika skor lebih kecil dari -2.22 maka perusahaan dikategorikan sebagai perusahaan yang tidak melakukan manipulasi (non fraud.).

\section{ANALISIS DATA DAN PEMBAHASAN}

Tabel 4.1 Hasil Uji Statistik t Fraud Pentagon

\begin{tabular}{|c|c|c|c|c|c|c|}
\hline & & & Coefficier & & & \\
\hline & & $\begin{array}{r}\text { Unsta } \\
\text { Coe }\end{array}$ & $\begin{array}{l}\text { lardized } \\
\text { cients }\end{array}$ & $\begin{array}{l}\text { Standardized } \\
\text { Coefficients }\end{array}$ & & \\
\hline & & $\mathrm{B}$ & Std. Error & Beta & $\mathrm{t}$ & Sig. \\
\hline 1 & (Constant) &, 147 & ,205 & &, 717 & ,476 \\
\hline & FS & ,112 & ,202 & ,074 &, 555 & 581, \\
\hline & AUD &,- 008 & ,095 &,- 011 &,- 086 & ,932 \\
\hline & CPA & ,206 & , 107 & ,263 & 1,930 & ,059 \\
\hline & DCHANGE & ,031 &, 122 & ,035 & ,256 & ,799 \\
\hline & $\mathrm{CEO}$ &,- 168 & ,205 &,- 114 &,- 822 & ,414 \\
\hline
\end{tabular}

Sumber : Data Sekunder yang diolah dengan spss 
Jurnal Ilmiah Akuntansi Universitas Pamulang - Vol. 9, No. 1, Januari 2021 - Sanulika \& Hidayati

\section{Pembahasan Hipotesis 1 : Pengaruh Financial Stability terhadap Fraudulent} Financial Reporting secara parsial.

Dari table uji t variabel Financial Stability menunjukkan nilai signifikan 0,581 lebih besar dari 0,05. Ini menunjukkan bahwa Financial Stability tidak perpengaruh terhadap Fraudulent Financial Reporting. Para manajer tidak serta merta akan memanipulasi laporan keuangan untuk meningkatkan prospek perusahaan ketika kondisi keuangan tidak stabil atau mengalami penurunan karena hal tersebut justru akan memperparah kondisi keuangan dimasa yang akan datang. Hasil ini didukung oleh penelitian yang dilakukan oleh Norbani dan Rahardjo (2012) yang menyatakan bahwa Financial Stability tidak berpengaruh secara signifikan terhadap financial statement fraud.

\section{Pembahasan Hipotesis 2 : Terdapat Pengaruh Kualitas Auditor Eksternal terhadap Fraudulent Financial Reporting secara parsial.}

Dari table uji t variabel kualitas auditor eksternal menunjukkan nilai signifikan 0,932 lebih besar dari 0,05. Ini menunjukkan bahwa kualitas auditor eksternal tidak perpengaruh terhadap Fraudulent Financial Reporting. Semua auditor baik yang tergolong KAP Big 4 maupun non Big 4 memiliki kedudukan yang sama, yaitu sama-sama harus mematuhi Standar Pemeriksaan Akuntan Publik dalam melaksanakan tugasnya. Hasil penelitian ini didukung oleh Fimanaya dan Syafruddin (2014), Tessa dan Harto (2016) yang mengatakan bahwa ukuran KAP tidak berpengaruh terhadap Fraudulent Financial Reporting.

\section{Pembahasan Hipotesis 3 : Terdapat pengaruh change in auditor terhadap Fraudulent Financial Reporting secara parsial.}

Dari table uji t variabel change in auditor menunjukkan nilai signifikan 0,059 lebih besar dari 0,05. Ini menunjukkan bahwa change in auditor tidak perpengaruh terhadap Fraudulent Financial Reporting. Karena perusahaan melakukan change in auditor bukan karena ingin mengurangi pendeteksian kecurangan laporan keuangan oleh auditor lama, tetapi dikarenakan perusahaan menaati Peraturan Pemerintah Republik Indonesia Nomor 20 Tahun 2015 pasal 11 ayat 1 yang menyatakan bahwa pemberian jasa audit atas laporan keuangan terhadap suatu entitas oleh seorang Akuntan Publik dibatasi paling lama 5 (lima) tahun buku berturut-turut. Hasil penelitian ini didukung oleh Tessa dan Harto (2016), Sihombing dan Rahardjo (2014)

\section{Pembahasan Hipotesis 4 : Terdapat pengaruh pergantian direksi perusahaan} terhadap Fraudulent Financial Reporting secara parsial.

Dari table uji $\mathrm{t}$ variabel pergantian direksi perusahaan menunjukkan nilai signifikan 0,799 lebih besar dari 0,05. Ini menunjukkan bahwa pergantian direksi perusahaan tidak perpengaruh terhadap Fraudulent Financial Reporting. Hal ini bisa dikarenakan setiap kerja direksi akan selalu diawasi dan dipantau oleh dewan komisaris. Sehingga direksi yang kerjanya tidak maksimal akan digantikan oleh direksi yang lebih berkompeten dan dapat bekerja secara maksimal guna 
Jurnal Ilmiah Akuntansi Universitas Pamulang - Vol. 9, No. 1, Januari 2021 - Sanulika \& Hidayati

meningkatkan kualitas perusahaan yang lebih baik lagi. Semakin tinggi kemampuan yang dimiliki direksi maka tingkat kehati-hatian dalam bekerja juga semakin tinggi sehingga kemungkinan melakukan kecurang sangat sedikit. Hasil penelitian ini didukung oleh Tessa dan Harto (2016), Annisya, Lindrianasari, dan Asmaranti (2016) serta Sihombing dan Rahardjo (2014) yang mengatakan bahwa pergantian direksi tidak berpengaruh signifikan terhadap kemungkinan Fraudulent Financial Reporting.

Pembahasan Hipotesis 5 : Terdapat pengaruh Frequent Number of CEO's Picture terhadap Fraudulent Financial Reporting secara parsial.

Dari table uji t variabel Frequent Number of CEO's Picture menunjukkan nilai signifikan 0,414 lebih besar dari 0,05. Ini menunjukkan bahwa Frequent Number of CEO's Picture tidak perpengaruh terhadap Fraudulent Financial Reporting. Hal ini dikarenakan, gambar CEO penting dicantumkan dalam laporan tahunan guna memperkenalkan kepada masyarakat luas terutama para pemangku kepentingan siapa CEO perusahaan tersebut. Foto yang dicantumkan dalam laporan tahunan yaitu foto hasil kegiatan, jika foto CEO ditampilkan dalam kegiatan tersebut membuktikan bahwa CEO ikut serta dalam setiap kegiatan yang dilakukan perusahaan. Sehingga masyarakat mampu menilai keseriusan, keuletan serta tanggung jawab CEO dalam memimpin perusahaan. Hasil penelitian ini didukung oleh Aprilia (2017) yang mengatakan bahwa variable frekuensi kemunculan gambar CEO tidak berpengaruh signifikan terhadap kecurangan laporan keuangan.

Tabel 4.2 Hasil Uji Statistik t Beneish Ratio

\begin{tabular}{|c|c|c|c|c|c|c|}
\hline \multicolumn{7}{|c|}{ Coefficients ${ }^{\mathrm{a}}$} \\
\hline \multirow[b]{2}{*}{ Model } & & \multicolumn{2}{|c|}{ Unstandardized Coefficients } & \multicolumn{2}{|l|}{$\begin{array}{c}\text { Standardized } \\
\text { Coefficients }\end{array}$} & \multirow[b]{2}{*}{ Sig. } \\
\hline & & B & Std. Error & Beta & $\mathrm{t}$ & \\
\hline 1 & (Constant) &,- 750 & , 176 & & $-4,259$ &, 000 \\
\hline & SDRI & 189 & , 110 & ,133 & 1,720 & 091 \\
\hline & GMI & ,173 & ,018 & ,632 & 9,872 &, 000 \\
\hline & AQI & ,019 & ,043 & ,031 & ,448 & ,656 \\
\hline & SGI & ,301 & ,040 & ,572 & 7,578 & ,000 \\
\hline & DEPI &,- 002 & ,011 &,- 014 &,- 222 &, 825 \\
\hline & SGAI &,- 031 & ,029 &,- 065 & $-1,065$ & 291 \\
\hline & LVGI & ,008 & ,019 & ,025 & ,412 & ,682 \\
\hline & TATA & 2,090 & ,739 & 174 & 2,827 & ,007 \\
\hline
\end{tabular}

Pembahasan Hipotesis 6 : Terdapat pengaruh days sales in receivable index terhadap Fraudulent Financial Reporting secara parsial.

Dari table uji t variabel Days Sales in Receivable Index menunjukkan nilai signifikan 0,091 lebih besar dari 0,05. Ini menunjukkan bahwa Days Sales in Receivable Index tidak perpengaruh terhadap Fraudulent Financial Reporting. Tidak adanya pengaruh variabel Days Sales in Receivable Index terhadap pendeteksian fraud. Hal ini tidak sejalan dengan Summers dan Sweeney, (1998) yang menyatakan bahwa manajer akan fokus terhadap kedua akun tersebut jika

* Corresponding author's e-mail: dosen01236@unpam.ac.id

http://openjournal.unpam.ac.id/index.php/JIA 
Jurnal Ilmiah Akuntansi Universitas Pamulang - Vol. 9, No. 1, Januari 2021 - Sanulika \& Hidayati

berniat melakukan manipulasi pada laporan keuangan.

Pembahasan Hipotesis 7 : Terdapat pengaruh Gross Margin Index terhadap Fraudulent Financial Reporting secara parsial.

Dari table uji t variabel Gross Margin Index menunjukkan nilai signifikan 0,000 lebih kecil dari 0,05. Ini menunjukkan bahwa gross margin index perpengaruh terhadap Fraudulent Financial Reporting. Apabila Gross Margin Index pada tahun terkait lebih kecil pada tahun sebelumnya hal ini mengindikasikan bahwa prospek perusahaan memburuk, sehingga perusahaan lebih mungkin untuk melakukan manipulasi. Hasil penelitian ini mendukung penelitian yang dilakukan oleh Tarjo dan Herawati (2015).

Pembahasan Hipotesis 8 : Terdapat pengaruh Asset Quality Index terhadap Fraudulent Financial Reporting secara parsial.

Dari table uji t variabel Asset Quality Index menunjukkan nilai signifikan 0,656 lebih besar dari 0,05. Ini menunjukkan bahwa Asset Quality Index ttidak perpengaruh terhadap Fraudulent Financial Reporting. Artinya bahwa besar kecilnya tingkat Asset Quality Index yang ditargetkan perusahaan tidak mempengaruhi manajemen untuk melakukan kecurangan laporan keuangan. Hasil penelitian ini berbeda dengan temuan Skousen et al. (2009) yang menyimpulkan bahwa Asset Quality Index berpengaruh positif terhadap Financial Statement Fraud. Tidak berpengaruhnya Asset Quality Index terhadap Financial Statement Fraud pada penelitian ini kemungkinan disebabkan karena manajer menganggap bahwa besarnya target Asset Quality Index perusahaan masih dinilai wajar dan bisa dicapai. Manajer tidak menganggap bahwa target Asset Quality Index tersebut sebagai target keuangan yang sulit untuk dicapai sehingga besarnya target Asset Quality Index tidak memicu terjadinya kecurangan laporan keuangan yang dilakukan oleh manajemen

\section{Pembahasan Hipotesis 9 : Terdapat pengaruh Sales Growth Index terhadap Fraudulent Financial Reporting secara parsial.}

Dari table uji t variabel Sales Growth Index menunjukkan nilai signifikan 0,000 lebih kecil dari 0,05. Ini menunjukkan bahwa Sales Growth Index perpengaruh terhadap Fraudulent Financial Reporting. Sesuai dengan SAS No. 99 manajer menghadapi tekanan (pressure) terkait Financial Statement Fraud ketika Financial Stability dan/atau profitability terancam oleh ekonomi, industri ataupun kondisi operasi perusahaan. Loebbecke et al. (1989) and Bell et al. (1991) Hal ini mengindikasikan bahwa di mana perusahaan mengalami pertumbuhan akan tetapi berada di bawah rata-rata industri sehingga manajer menghadapi tekanan dan akan memanipulasi laporan. Hasil ini mendukung penelitian yang dilakukan oleh Beneish (1999) dan Roxas (2011).

Pembahasan Hipotesis 10 : Terdapat pengaruh depreciation index (DEPI) terhadap Fraudulent Financial Reporting secara parsial.

Dari table uji t variabel Depreciation Index menunjukkan nilai signifikan 0,825 lebih besar dari 0,05. Ini menunjukkan bahwa Depreciation Index tidak 
Jurnal Ilmiah Akuntansi Universitas Pamulang - Vol. 9, No. 1, Januari 2021 - Sanulika \& Hidayati

perpengaruh terhadap Fraudulent Financial Reporting. ini disebabkan oleh suatu kebijakan penyusutan yang diterapkan dan dilakukan oleh perusahaan telah sesuai dengan kebijakan yang berlaku.

Pembahasan Hipotesis 10 : Terdapat pengaruh Sales and General Administration Expenses Index terhadap Fraudulent Financial Reporting secara parsial.

Dari table uji t variabel Sales and General Administration Expenses Index menunjukkan nilai signifikan 0,291 lebih besar dari 0,05. Ini menunjukkan bahwa depreciation index tidak perpengaruh terhadap Fraudulent Financial Reporting. Hal ini dikarenakan ketika suatu perusahaan dapat mempertahankan aktivitas penjualannya maka perusahaan tidak dapat melakukan fraud dengan cara memanfaatkan aset perusahaan untuk menghasilkan pendapatan. Hal ini tidak sesuai dengan pendapat Summers dan Sweeney (1998, dalam Skousen et al.,2008) akun persediaan dan piutang dapat digunakan untuk mengidentifikasi manipulasi laporan keuangan.

Pembahasan Hipotesis 12 : Terdapat pengaruh leverage index terhadap Fraudulent Financial Reporting secara parsial.

Dari table uji t variabel Leverage Index menunjukkan nilai signifikan 0,682 lebih besar dari 0,05. Ini menunjukkan bahwa leverage index tidak perpengaruh terhadap Fraudulent Financial Reporting. Leverage Index tidak memberikan pengaruh terhadap pendeteksian fraud. Hal ini dikarenakan besar kecilnya rasio perubahan dalam piutang usaha tidak memicu manajemen untuk melakukan kecurangan laporan keuangan. Hasil penelitian ini sejalan dengan pendapat Person (1999) yang menyatakan bahwa leverage yang lebih besar dapat dikaitkan dengan kemungkinan yang lebih besar untuk melakukan pelanggaran terhadap perjanjian kredit dan kemampuan yang lebih rendah untuk memperoleh tambahan modal melalui pinjaman

Pembahasan Hipotesis 13 : Terdapat pengaruh Total Accrual terhadap Fraudulent Financial Reporting secara parsial.

Dari table uji t variabel Total Accrual menunjukkan nilai signifikan 0,007 lebih besar dari 0,05. Ini menunjukkan bahwa Total Accrual tidak perpengaruh terhadap Fraudulent Financial Reporting . Rasio Total Accrual to Total Asset merupakan pendapatan dan beban yang akan dicatat atau diakui pada saat terjadinya transaksi. Rasio inimengukur pendapatan yang berbasis kas. Penelitian yang sama dengan hasil penelitian ini adalah penelitian yang dilakukan oleh Tarjo dan Herawati (2015) dan Beneish (1999)

Tabel 4.3 Hasil Uji f Determinasi Fraud Pentagon

\begin{tabular}{|c|c|c|c|c|c|c|}
\hline \multicolumn{7}{|c|}{ ANOVA $^{a}$} \\
\hline \multicolumn{2}{|c|}{ Model } & $\begin{array}{l}\text { Sum of } \\
\text { Squares }\end{array}$ & $\mathrm{df}$ & Mean Square & $\mathrm{F}$ & Sig. \\
\hline 1 & Regression & ,683 & 5 & , 137 & 1,056 & $394^{\mathrm{b}}$ \\
\hline & Residual & 7,508 & 58 & , 129 & & \\
\hline
\end{tabular}

* Corresponding author's e-mail: dosen01236@unpam.ac.id

http://openjournal.unpam.ac.id/index.php/JIA 
Jurnal Ilmiah Akuntansi Universitas Pamulang - Vol. 9, No. 1, Januari 2021 - Sanulika \& Hidayati

\begin{tabular}{cc}
\hline Total & 8,191 \\
Sumber: Data Sekunder yang diolah dengan spss
\end{tabular}

Tabel 4.4 Hasil Uji f Determinasi Beneish Ratio

\begin{tabular}{llcrrrr}
\hline \multicolumn{2}{c}{ ANOVA $^{\text {a }}$} & & & & \\
Model & & \multicolumn{2}{c}{ Sum of } \\
Squares & df & & Mean Square & \multicolumn{1}{c}{ F } & Sig. \\
\hline 1 & Regression & 6,646 & 8 &, 831 & 29,572 &, $000^{\text {b }}$ \\
& Residual & 1,545 & 55 &, 028 & & \\
& Total & 8,191 & 63 & & & \\
\hline
\end{tabular}

Sumber : Data Sekunder Yang Diolah dengan spss

Pembahasan Hipotesis 14 : Terdapat pengaruh Financial Stability, Kualitas Auditor Eksternal, Change in Auditor, Change of Drectors, Frequent Number of CEO's Picture terhadap Fraudulent Financial Reporting secara simultan.

Dari table uji f menunjukkan nilai signifikan 0,394 lebih besar dari 0,05. Maka dapat disimpulkan FraudPentagon yang diproksikan dengan variabel Financial Stability, Kualitas Auditor Eksternal, Kualitas Auditor Eksternal , ChangeiIn Auditor, Change of Drectors, Frequent Number Of CEO's Picture tidak berpengaruh terhadap Fraudulent Financial Reporting secara simultan.

Pembahasan Hipotesis 15 : Terdapat pengaruh Days Sales in Receivable Index, Sales Gross Margin Index, Asset Quality Index, Growth Index, Depreciation Index, Sales and General Administration Expenses Index, Leverage Index, Total Accrual terhadap Fraudulent Financial Reporting secara simultan.

Dari table uji f menunjukkan nilai signifikan 0,000 lebih kecil dari 0,05. Maka dapat disimpulkan Beneish Ratio yang diproksikan dengan variabel days sales in receivable index, sales gross margin index, Asset Quality Index, growth index, depreciation index, sales and general administration expenses index, leverage index, total accrual berpengaruh secara simultan terhadap fraudulent financial reporting. 
Jurnal Ilmiah Akuntansi Universitas Pamulang - Vol. 9, No. 1, Januari 2021 - Sanulika \& Hidayati

Tabel 4.5

Hasil Moderated Regression Analysis (MRA)

\begin{tabular}{|c|c|c|c|c|c|c|}
\hline & & \multicolumn{2}{|c|}{$\begin{array}{l}\text { Unstandardized } \\
\text { Coefficients }\end{array}$} & \multirow{2}{*}{$\begin{array}{c}\begin{array}{c}\text { Standardized } \\
\text { Coefficients }\end{array} \\
\text { Beta } \\
\end{array}$} & \multirow[b]{2}{*}{$\mathrm{t}$} & \multirow[b]{2}{*}{ Sig. } \\
\hline \multicolumn{2}{|c|}{ Model } & $\mathrm{B}$ & Std. Error & & & \\
\hline \multirow[t]{14}{*}{1} & (Constant) & $-1,120$ &, 204 & & $-5,482$ & .000 \\
\hline & FS & -479 & $=131$ & -319 & $-3,652$ & 001 \\
\hline & AUD &, 016 &, 041 &, 023 &, 392 & 697 \\
\hline & CPA &, 060 & .048 & .077 & 1,270 &, 210 \\
\hline & DCHANGE & $=007$ & .053 & 008 & 132 & 896 \\
\hline & CEO & -057 &, 092 &,- 039 & -.622 & .537 \\
\hline & SDRI & .527 & .143 & 371 & 3,678 & 001 \\
\hline & GMII & .173 & .016 &, 632 & 11,046 & 000 \\
\hline & $\mathrm{AQI}$ & 049 & $=039$ & 078 & 1,237 & .222 \\
\hline & SGI &, 390 & $=049$ & 743 & 8,544 & 2000 \\
\hline & DEPI & $=012$ & $=011$ & .067 & 1,142 & 259 \\
\hline & SGAI &,- 027 &, 020 &,- 058 & $-1,068$ & 290 \\
\hline & LVGI & $=001$ & $=017$ & .002 & 030 & 976 \\
\hline & TATA & 1,304 &, 672 &, 108 & 1,940 &, 058 \\
\hline
\end{tabular}

Pembahasan Hipotesis 16 : Opini Audit mampu memoderasi Financial Stability, Kualitas Auditor Eksternal, Change in Auditor, Change of Drectors, Days Sales in Receivable Index, Sales Gross Margin Index, Asset Quality Index, Growth Index, Depreciation Index, Sales and General Administration Expenses Index, Leverage Index, Total Accrual terhadap Fraudulent Financial Reporting.

Opini wajar tanpa pengecualian merupakan salah satu bentuk opini dari pihak independen yang dapat meningkatkan pengaruh Financial Stability, Kualitas Auditor Eksternal, Change in Auditor, Change of Drectors, Days Sales in Receivable Index, Sales Gross Margin Index, Asset Quality Index, Growth Index, Depreciation Index, Sales and General Administration Expenses Index, Leverage Index, Total Accrual terhadap Fraudulent Financial Reporting.

Perbandingan Fraud Pentagon dengan Beneish Ratio dalam pengaruh terhadap Fraudulent Financial Reporting

Nilai signifikan pesamaan model Beneish Ratio dari table uji f menunjukkan nilai signifikan 0,000 lebih kecil dari 0,05. Dan pesamaan model Fraud Pentagon dari table uji $\mathrm{f}$ menunjukkan nilai signifikan 0,394 lebih besar dari 0,05. Yang artinya Fraud Pentagon tidak berpengaruh terhadap Fraudulent Financial Reporting. Sehingga dapat disimpulkan bahwa Beneish Ratio berpengaruh terhadap Fraudulent Financial Reporting dibandingkan Fraud Pentagon.

\section{KESIMPULAN DAN SARAN}

\section{Kesimpulan}

Berdasarkan hasil penelitian yang telah dilakukan dapat diambil kesimpulan sebagai berikut:

1. Dari 64 sampel terdapat $12,5 \%$ yang mengindikasikan bahwa laporan keuangan telah dimanipulasi. 
Jurnal Ilmiah Akuntansi Universitas Pamulang - Vol. 9, No. 1, Januari 2021 - Sanulika \& Hidayati

2. variabel Financial Stability, kualitas auditor eksternal, kualitas auditor eksternal, change in auditor, change of drectors, Frequent Number of CEO's Picture secara simultan tidak berpengaruh terhadap Fraudulent Financial Reporting.

3. variabel days sales in receivable index, sales gross margin index, Asset Quality Index, growth index, depreciation index, sales and general administration expenses index, leverage index, total accrual secara simultan berpengaruh terhadap Fraudulent Financial Reporting.

4. Opini audit mampu memoderasi pengaruh Beneish Ratio terhadap Fraudulent Financial Reporting.

5. Beneish Ratio berpengaruh terhadap Fraudulent Financial Reporting dibandingkan Fraud Pentagon.

\section{Saran}

\section{Perusahaan Perbankan}

Bagi perusahaan perbankan khususnya dan perusahaan go public umumnya diharapkan lebih meningkatkan tingkat kehati-hatian dalam memberikan informasi kepada public agar tidak menyesatkan para pembaca laporan keuangan. Hal ini dikarenakan seiring dengan perkembangan zaman para pemangku kepentingan jauh lebih pandai dalam mendeteksi adanya kecurangan laporan keuangan.

\section{Bagi peneliti selanjutnya}

Peneliti selanjutnya disarankan mengganti proksi dari elemen fraud pentagon agar mendapatkan hasil yang empiris. Banyak proksi lain yang bisa digunakan peneliti untuk membuktikan dari beberapa elemen tersebut, misalnya politisi CEO, pergantian kebijakan perusahaan, kepemilikan manajerial, pergantian ketua auditor internal dan masih banyak lagi.

\section{Bagi Shareholder}

Para shareholder disarankan lebih hati-hati dalam menentukan pilihan untuk berinvestasi. Hal ini dikarenakan untuk mengantisapasi adanya kecurangan yang dilakukan perusahaan. Shareholder bisa menggunakan cara pendeteksian seperti yang dilakukan oleh peneliti guna mendeteksi adanya kecurangan laporan keuangan.

\section{DAFTAR PUSTAKA}

Annisya, M., Lindrianasari, \& Asmaranti, Y. (2016). Pendeteksian Kecurangan Laporan Keuangan Menggunakan Fraud Diamond. Jurnal Bisnis dan Manajemen, 23(1), 72-89.

Aprilia. (2017). Analisa Pengaruh Fraud Pentagon Terhadap Kecurangan Laporan Keuangan Menggunakan Beneish Model pada Perusahaan yang Menerapkan Asean Corporate Governance Scorecard. Jurnal Akuntansi Riset, 6(1), 96-126. 
Jurnal Ilmiah Akuntansi Universitas Pamulang - Vol. 9, No. 1, Januari 2021 - Sanulika \& Hidayati

Beneish, M. D. (1999). The Detection of Earnings Manipulation. Financial Analysts Journal, 55(5), 24-36.

Hariri, Ayub Wijayanti, dan Srilucki W.. (2013). Predicitng Financial Statements Corporate Fraud: Beneish M-Score Model. International Journal of Trade, Economics and Financial. 5(2).

Loebbecke, J., M. Eining. and J. Willingham. (1989). Auditor's Experience with Material Irregularities: Frequency, Nature, and Detectability. Auditing: A Journal of Practice \& Theory. 1(28).

Sekaran, U. (2006). Metode Penelitian untuk Bisnis, Terjemahan, Widyaningrum. Jakarta: Salemba Empat.

Sihombing, K. S., \& Rahardjo, S. N. (2014). Analisis Fraud Diamond dalam Mendeteksi Financial Statement Fraud: Studi Empiris pada Perusahaan Manufaktur yang Terdaftar di Bursa Efek Indonesia (BEI) Tahun 20102012. Diponegoro Journal of Accounting, 3(2), 1-12.

Sugiyono. (2007). Memahami Penelitian Kualitatif. Bandung: CV. Alfabeta.

Supomo, B \& Indriantoro, N. (2004). Metodologi Penelitian Bisnis untuk Akuntansi dan Manajemen. Yogyakarta: BPFE.

Tarjo, \& Herawati, N. (2015). Application of Beneish M-Score Models andData Mining to Detect Financial Fraud. Procedia - Social and Behavioral Sciences, 211(2015), 924-930.

Tessa, C \& Harto, P. (2016). Fraudulent Financial Reporting: Pengujian Teori Fraud Pentagon Pada Sektor Keuangan dan Perbankan di Indonesia. Simposium Nasional Akuntansi XIX. 1-12.

Widarti. (2015). Pengaruh Fraud Triangle Terhadap Deteksi Kecurangan Laporan Keuangan Pada Perusahaan Manufaktur yang Terdaftar di Bursa Efek Indonesia (BEI). Jurnal Manajemen dan Bisnis Sriwijaya, 13(2), $229--244$. 